\title{
Variation in the annual growth, by sex and migration history, of silver American eels Anguilla rostrata
}

\author{
B. M. Jessop ${ }^{1, *}$, J. C. Shiao ${ }^{2}$, Y. Iizuka ${ }^{3}$, W. N. Tzeng ${ }^{4}$ \\ ${ }^{1}$ Department of Fisheries and Oceans, Bedford Institute of Oceanography, PO Box 1006, Dartmouth, \\ Nova Scotia B2Y 4A2, Canada \\ ${ }^{2}$ Institute of Zoology, and ${ }^{3}$ Institute of Earth Sciences, Academia Sinica, Nankang, Taipei, Taiwan 11529, ROC \\ ${ }^{4}$ Institute of Fisheries Sciences, College of Life Science, National Taiwan University, Taipei, Taiwan 10617, ROC
}

\begin{abstract}
Silver American eels Anguilla rostrata from the East River, Chester, on the Atlantic coast of Nova Scotia, as evaluated by the temporal pattern of Sr:Ca ratios in their otoliths, showed variable patterns of migration between river and estuarine/marine waters during their yellow eel stage. Eels with a history of primarily estuarine residence were longer (total length) at migration and had higher annual growth rates than did eels with a primarily freshwater residence. Female eels were longer at migration and had higher annual growth rates than did males. The percentage $(64 \%)$ of silver eels with a history of estuarine residence and their larger size at age, size at migration, and higher growth rate relative to freshwater resident eels may result from higher productivity in oceanic than freshwaters at higher latitudes, as modified by regional environmental conditions. Environmental conditions change with increasing latitude in a different pattern for American and Japanese eels than for European eels.
\end{abstract}

KEY WORDS: Anguilla rostrata $\cdot$ American eel $\cdot$ Otolith microchemistry $\cdot$ Strontium:calcium ratios · Migratory history

Resale or republication not permitted without written consent of the publisher

\section{INTRODUCTION}

Concern exists about declines in river-specific stocks of, and the perceived effects of such declines on, the larger populations of the highly valued and intensively fished species of temperate-zone Anguilla and the subsequent production of sexually maturing (silver) eels (Peterson 1997, ASMFC 2000, Haro et al. 2000, ICES 2001，2003, Tatsukawa 2003). River-specific declines in silver eel production may occur due to the harvesting of older and faster growing juvenile (yellow) eels (Svedäng 1999, Dekker 2000) but insufficient information exists to determine whether there is a population-wide decline in silver eel production over the continental range (Greenland to northern South America; Tesch 1977) of the American eel Anguilla rostrata (Haro et al. 2000, ICES 2001), although a recent report
(Dekker et al. 2003) concludes that such a decline has occurred.

Localized differences in habitat conditions and high exploitation of American eels may induce effects such as a decrease in age and size at maturity and increased growth rate, amongst other factors, that may also occur in marine and anadromous species (Vøllestad 1992, Rijnsdorp 1993, Trippel 1995, Oliveira \& McCleave 2000, Stokes \& Law 2000). For the panmictic American eel (Avise et al. 1986), localized differences in lifehistory patterns are likely to be phenotypic in origin rather than genotypic and not heritable in a stockspecific manner. However, before specific hypotheses can be tested, better information is needed on the geographic and temporal change in life-history characteristics of specific stocks under varying regimes of exploitation. 
Few studies have examined aspects of the annual growth rates for each sex and the age and sex composition at migration of silver American eels (Gray \& Andrews 1971, Helfman et al. 1984, Bouillon \& Haedrich 1985, Jessop 1987, Oliveira 1999). The different lifehistory strategies (female eels typically migrate at larger sizes and older ages than do males) and usually higher annual growth rates for female eels than for males requires analysis of such sexual differences (Helfman et al. 1984, Jessop 1987, Oliveira 1999, Oliveira \& McCleave 2002). Although the presence of yellow eel fisheries in the watershed may affect the biological composition of the stock, few have reported specifically on the presence or absence of such fisheries. This study examines the age composition and growth rates, for each sex, of silver American eels from a river unexploited for yellow eels (and infrequently exploited for silver eels) and where no estuarine fishery occurs.

The environmental history of fishes has been examined by analysis of the spatial and, by inference, temporal pattern of Sr:Ca ratios in their otoliths (Secor et al. 1995, Secor 1999, Secor \& Rooker 2000), with much attention given to Anguilla spp. (Otake et al. 1994, Tzeng \& Tsai 1994, Tzeng 1996, Tzeng et al. 1997, 2000b, 2002, 2003, Jessop et al. 2002) and many others.

Although water temperature may have a significant effect on the otolith Sr:Ca ratio and the interaction of water temperature and salinity may be important in the interpretation of fish migratory patterns based on Sr:Ca ratios (Elsdon \& Gillanders 2002), the chemistry of the ambient environment is the primary factor (Bath et al. 2000) and marine waters have a Sr:Ca ratio ca. 4.8 times higher than do fresh waters $\left(8.6 \times 10^{-3}\right.$ vs $1.8 \times 10^{-3}$; Campana 1999). The maximum difference between mean otolith $\mathrm{Sr}$ :Ca ratios of a juvenile marine fish was ca. $1.3 \times 10^{-3}$ over a wide range of temperatures and salinities (Elsdon \& Gillanders 2002). Such a potential bias is unlikely to affect the interpretation of fish migratory patterns except in the transition between saline and freshwater environments and, given that the bias may be positive or negative and often less than the maximum, may have little practical effect.

Tsukamoto \& Arai (2001) have shown that Anguilla spp. may be facultatively rather than obligatorily catadromous and that several ecophenotypes or migratory contingents may occur, including yellow eels that migrate irregularly between freshwater and the estuary (Tsukamoto \& Arai 2001, Jessop et al. 2002). Fish migration between marine and freshwater habitats may generally be explained by differences in the availability of food, and in high latitudes the productivity of freshwaters may be lower than in adjacent estuaries (Gross 1987, Gross et al. 1988). Thus, Tsukamoto \& Arai (2001) and Tsukamoto et al. (2002) have hypothesized that marine/estuarine residency of Anguilla spp. should occur more frequently at high latitudes where the productivity of the freshwater habitat is lower than that of adjacent coastal regions.

This hypothesis can be interpreted in at least 3 ways: (1) that the abundance of eels in a given coastal/estuarine zone relative to their abundance in the watersheds of adjacent river systems increases at higher latitudes, as does both (2) the proportion of eels in a river or estuary showing evidence of periodic migration between freshwater and estuarine habitats, and (3) the proportion of eels totally resident in a marine/estuarine habitat (the sea eels of Tsukamoto \& Arai 2001 and Tzeng et al. 2002). The absolute or relative abundance of eels in a river system and its receiving estuarine and coastal areas is unknown for any North American river system (Haro et al. 2000), or for Europe or Asia. However, $64 \%$ of silver eels migrating from a river on the Atlantic coast of Nova Scotia, Canada (Jessop et al. 2002) showed evidence of freshwater-estuarine migration as yellow eels, as did $65 \%$ of yellow eels in the estuarine portion of the lower Hudson River, New York (Morrison et al. 2003), which supports the second interpretation of the hypothesis. We will examine the implication in the second part of the hypothesis that such a migratory contingent of American eels from the East River, Nova Scotia in the northern portion of their range will show differences in annual growth rates reflective of their relative residence times in fresh and estuarine waters. Thus, eels that have spent most of their life in freshwater should have a slower annual growth rate than do eels that have resided mostly in the estuary.

\section{MATERIALS AND METHODS}

Study area. The East River (near Chester, Nova Scotia, at latitude $44^{\circ} 35^{\prime} 16^{\prime \prime} \mathrm{N}$ ) drains a watershed of $134 \mathrm{~km}^{2}$, of which $10.5 \%$ is lake surface, into Mahone Bay, which is located slightly south of the mid-point along the Atlantic coast of Nova Scotia, Canada (Fig. 1). River discharge ranges from $<5 \mathrm{~m}^{3} \mathrm{~s}^{-1}$ during the summer to perhaps $35 \mathrm{~m}^{3} \mathrm{~s}^{-1}$ during the spring flood. Conifers dominate the watershed forest. The water basin geology consists mostly of granite and metamorphic rocks overlain by shallow soils with poor drainage and containing numerous lakes and many bogs and heaths, with resultant acidification ( $\mathrm{pH}$ range 4.7 to 5.0 ) of the water (Watt 1986, Watt et al. 1995). Jessop (2000) and Jessop et al. (2002) provide a more detailed description of the river.

Sample collection. Downstream migrant silver eels were collected between September 28 and 30, 1998, from a weir located $1.3 \mathrm{~km}$ upstream from the river mouth (Site B, Fig. 1). Of the 91 silver eels caught 

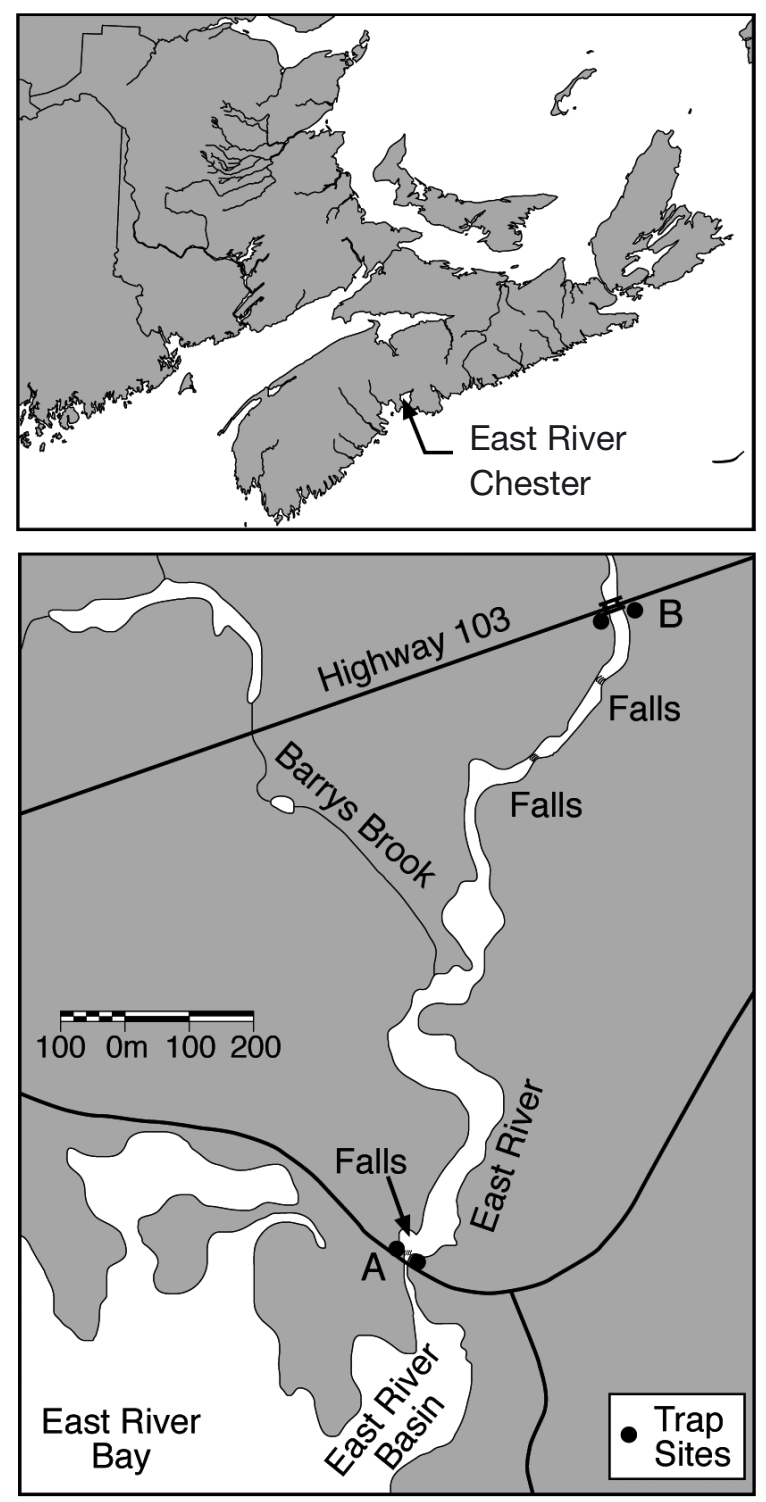

Fig. 1. Map of the East River, Chester, Nova Scotia, showing the geographic location of the river (upper panel) and sampling sites (lower panel) before the weir washed out due to flooding, 61 were representatively selected for otolith analysis. Upstream migrant juvenile eels were collected in elver traps located just upstream of the head of tide (Site A, Fig. 1) and later at Site B. At Site A, the traps caught 1202 upstream migrant juvenile eels between May 2 and July 25, 2000 (Jessop 2003a), from which up to 6 juveniles per $10 \mathrm{~mm}$ length interval over the range of lengths from 70 to $150+\mathrm{mm}$ (total $\mathrm{n}=44$ ) were systematically collected between May 5 and June 19, with 37 selected for otolith analysis (Table 1). At Site B, of 30 elver/juvenile eels collected on June 28, 19 were selected for otolith analysis. The silver eels were frozen after capture and then thawed prior to length (to $1.0 \mathrm{~mm}$ ) measurement. Freezing and thawing produce a shrinkage of ca. $1.6 \%$ in American eels of lengths ca. 400 mm (W. Morrison, Chesapeake Bay Biological Laboratory, pers. comm.). The silver eel heads were then preserved in $95 \%$ ethanol for later extraction of the otoliths. The juvenile eels were, after anaesthetization in MS-222, measured for length (total length [TL] to $0.1 \mathrm{~mm}$ for eels less than $100 \mathrm{~mm}$ and to $1.0 \mathrm{~mm}$ for larger eels) and then preserved in $95 \%$ ethanol until otolith extraction. The length distributions of juvenile eels selected for otolith extraction were matched with their length distributions when freshly measured and a linear conversion equation developed $(\mathrm{PL}=3.681+$ $0.908 \mathrm{FL}$, where PL is preserved length and FL is fresh length in $\mathrm{mm}$ over the range from 60 to $180 \mathrm{~mm} ; \mathrm{n}=36$, $\left.r^{2}=0.998, p<0.001\right)$. Reported lengths were adjusted, as appropriate, for ethanol preservation and freezing. Juvenile eels were not sexed because all were of a size $(<180 \mathrm{~mm})$ and age ( $\leq 4 \mathrm{yr})$ where few, if any, would be sexually differentiated (Jessop 1987, Oliveira \& McCleave 2002). The sex of the silver eels was evaluated macroscopically (testes were deeply lobed while ovaries were frilled and ribbon-like; Bertin 1956, Krueger \& Oliveira 1997) and then compared with the generally accepted idea that male silver eels are typically less than 400 mm long (Krueger \& Oliveira 1997).

Table 1. Anguilla rostrata. Sample data for microchemistry analysis of otoliths of American eels collected from the East River, Nova Scotia. Undiff.: undifferentiated gonads

\begin{tabular}{|c|c|c|c|c|c|c|c|c|c|c|}
\hline \multirow[t]{2}{*}{ Group } & \multirow{2}{*}{$\begin{array}{l}\text { Sampling date } \\
\text { (dd/mm/yy) }\end{array}$} & \multirow[t]{2}{*}{ Site } & \multirow[t]{2}{*}{ Stage } & \multirow[t]{2}{*}{ Sex } & \multirow[t]{2}{*}{$\mathrm{N}$} & \multirow[t]{2}{*}{ Age (yr) } & \multicolumn{2}{|c|}{ Length (mm) } & \multicolumn{2}{|c|}{ Weight (g) } \\
\hline & & & & & & & Mean \pm SD & Range & Mean \pm SD & Range \\
\hline 1 & $05-19 / 06 / 00$ & $\begin{array}{l}\text { River } \\
\text { mouth }\end{array}$ & Juvenile & Undiff. & 29 & $1-4$ & $101.9 \pm 25.84$ & $72.4-180.1$ & $1.42 \pm 1.650$ & $0.29-8.2$ \\
\hline 2 & $05-22 / 06 / 00$ & $\begin{array}{l}\text { River } \\
\text { mouth }\end{array}$ & Juvenile & Undiff. & 8 & 1 & $66.0 \pm 2.94$ & $62.0-69.8$ & $0.25 \pm 0.068$ & $0.14-0.32$ \\
\hline 3 & $28 / 06 / 00$ & $\begin{array}{l}1.3 \mathrm{~km} \\
\text { upriver }\end{array}$ & $\begin{array}{c}\text { Elver/ } \\
\text { juvenile }\end{array}$ & Undiff. & 19 & $1-2$ & $70.9 \pm 6.05$ & $63.0-84.0$ & $0.33 \pm 0.108$ & $0.19-0.58$ \\
\hline 4 & $28-30 / 09 / 98$ & $\begin{array}{c}1.3 \mathrm{~km} \\
\text { upriver }\end{array}$ & Silver $^{\mathrm{a}}$ & $\begin{array}{c}\text { Male } \\
\text { Female }\end{array}$ & $\begin{array}{l}35 \\
26\end{array}$ & $\begin{array}{l}10-25 \\
11-29\end{array}$ & $\begin{array}{l}354.4 \pm 18.0 \\
467.6 \pm 86.6\end{array}$ & $\begin{array}{l}326-412 \\
378-740\end{array}$ & $\begin{array}{c}78.9 \pm 10.04 \\
207.5 \pm 176.71\end{array}$ & $\begin{array}{l}62.7-115.2 \\
92.6-882.2\end{array}$ \\
\hline
\end{tabular}


Otolith preparation and measurement. Sagittal otoliths were removed, prepared for electron probe microanalysis and the $\mathrm{Sr}$ and $\mathrm{Ca}$ concentration measured along a transect of the sagittal plane of the otolith from the primordium to the otolith edge as described by Tzeng et al. (1997) and Jessop et al. (2002). The environmental history of each eel was interpreted by examining the temporal pattern of $\mathrm{Sr}: \mathrm{Ca}$ ratios along the otolith transect, under the assumption that the temporal pattern reflects habitat salinity in response to the positive relation between otolith $\mathrm{Sr}$ :Ca ratio and ambient salinity in marine, estuarine and freshwater fishes (Tzeng 1996, Kawakami et al. 1998, Secor \& Rooker 2000). We considered Sr:Ca ratios less than $4.0 \times 10^{-3}$ to indicate freshwater residence and values greater than $5.0 \times 10^{-3}$ to indicate estuarine residence, with intermediate values representing a change in habitat (Jessop et al. 2002) (Fig. 2).

Migratory classification. Each eel was classified, based on the pattern and value of the Sr:Ca ratio measurements, into 1 of 4 migratory groups, or contingents, following Jessop et al. (2002):

Group 1: Entrance to freshwater as an elver and remaining in freshwater until capture as a juvenile (yellow) eel or maturing (silver) eel.

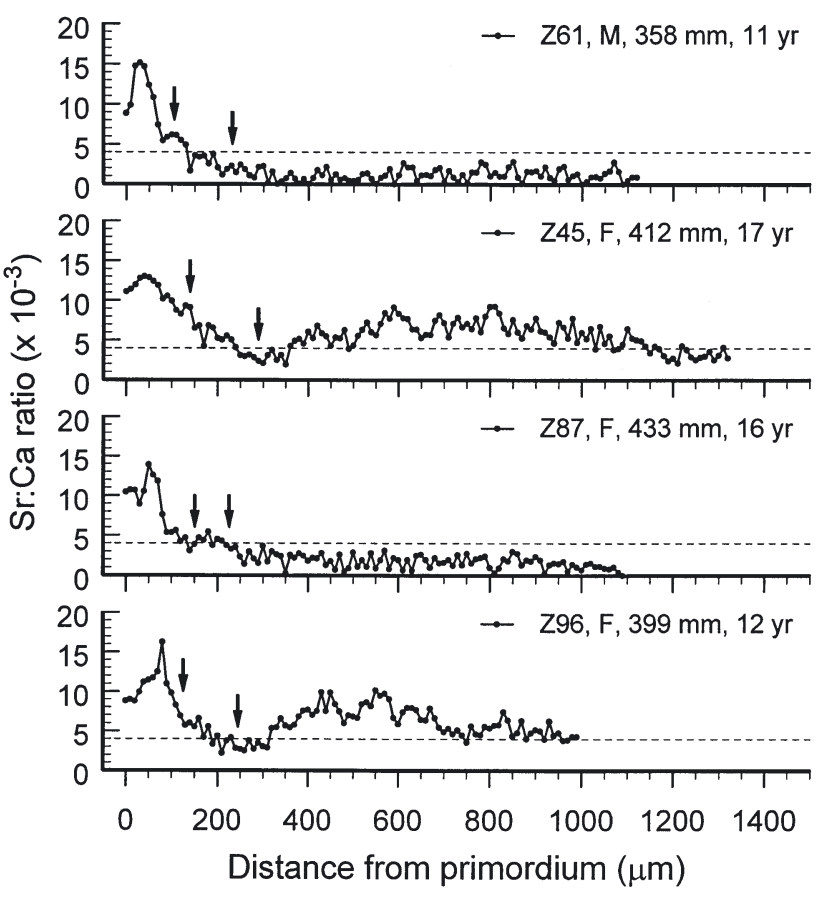

Fig. 2. Anguilla rostrata. Sr:Ca ratio transects along the otolith radius from the core to the edge illustrating various patterns of movement and residence history of silver American eels from the East River, Nova Scotia. The horizontal line at a $\mathrm{Sr}$ :Ca ratio of $4 \times 10^{-3}$ represents the transition between fresh and saline waters, while the arrows indicate the freshwater check and first annulus
Group 2: Entrance to freshwater as an elver and remaining in the river for a variable number of years before returning to the estuary for a variable number of years and finally returning to the river before capture.

Group 3: Entrance to freshwater as a juvenile after one or more years in the estuary, then remaining in the river until capture.

Group 4: Entrance to freshwater as a juvenile after one or more years in the estuary, then remaining in the river for a variable number of years before returning to the estuary for a variable number of years and finally returning to the river before capture.

The percentage of freshwater residence, after initial river entrance, for migration Groups 1 and 2 was based on the percent of $\mathrm{Sr}$ :Ca measurement values along the otolith transect that were $\leq 4.0 \times 10^{-3}$, as measured from the first Sr:Ca value of the first pair of $\mathrm{Sr}$ :Ca values $\leq 4.0 \times 10^{-3}$ (typically 5 to 10 measurement spots after the elver check, nominally the freshwater check). For migration Groups 3 and 4, the transect was divided into 2 sections: (1) from the freshwater check to the last $\mathrm{Sr}$ : Ca value $>4.0 \times 10^{-3}$, which covers the period from entrance to the estuary to entrance to freshwater, and (2) from the first $\mathrm{Sr}: \mathrm{Ca}$ value of the first pair of $\mathrm{Sr}$ :Ca values $\leq 4.0 \times 10^{-3}$ to the otolith edge, which covers the period from initial freshwater entrance to migration downstream as a silver eel. The freshwater residence period was estimated as the percentage of $\mathrm{Sr}$ :Ca ratio values $\leq 4.0 \times 10^{-3}$ following initial freshwater entrance.

Otolith measurement and back-calculation procedures. After microprobe analysis, the otoliths were repolished and etched with 5\% EDTA to enhance the annuli (Tzeng et al. 1994). All of the otoliths analyzed for Sr:Ca ratio were aged by counting annuli, and the distances were measured (to $0.001 \mathrm{~mm}$ ) by image analysis software along the longest radius (usually, unless another radius permitted better visualization) from the core to the outer edge of various life-stage markers and the otolith edge, e.g. freshwater check at the transition from glass eel to elver and the annuli marking the age in years. Oliveira (1996) confirmed that otolith ring formation was annual for yellow American eels in a Rhode Island river in the northeastern United States. For the purpose of examining the body length-otolith radius relation, data were included from an additional 12 juvenile eels (TL range 62.3 to $79.5 \mathrm{~mm}$ ) from the East River, Chester, Nova Scotia, and from 25 elvers (TL range 53.6 to $69.9 \mathrm{~mm}$ ) from the East River, Sheet Harbour, Nova Scotia (located ca. $130 \mathrm{~km}$ NE of the East River, Chester). Jessop (2003a) observed that elvers appear to be in a different growth stanza than are larger juvenile eels, and a plot of the body length-otolith radius data (Fig. 3) indicated a 


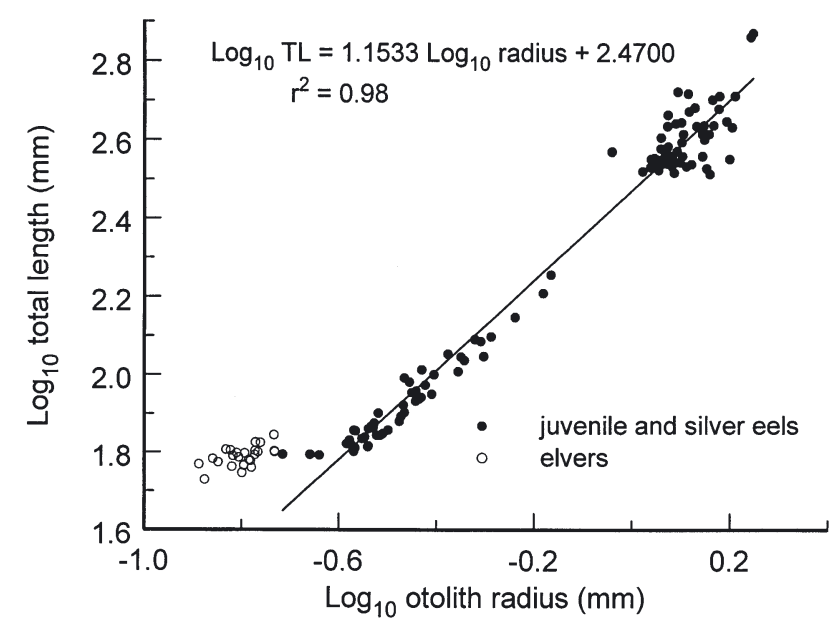

Fig. 3. Anguilla rostrata. Relationship between the total length $(\mathrm{mm})$ and otolith radius $(\mathrm{mm})$ appropriate to the $\mathrm{BPH}$ (body proportional hypothesis) back-calculation model for elvers, juvenile (yellow), and silver American eels from Nova Scotia

difference in this relation between elvers and larger juvenile eels. Consequently, the body length-otolith radius relation used for back-calculation of juvenile and silver eel lengths-at-age was based only on data from the juvenile and silver eel life stages.

No obvious reason exists to prefer either the 'scale proportional' (SPH) or 'body proportional' (BPH) hypotheses, which assume either a constant proportional deviation from the mean size of the scale or body, and procedures for the purpose of back-calculating lengthat-age from the relationship between otolith radii lengths at each annulus and eel TL (OR-TL relation) (Francis 1990, 1995). Given that each model can produce very different back-calculated lengths-at-age from the same data, the differences between the methods in estimating length-at-age can provide a minimum measure of the variability of back-calculation. For both the SPH and BPH models, linear regressions $\left(\mathrm{r}^{2}=0.980\right.$; quadratic polynomial models provided trivial improvement in fit) were fitted to the appropriate distribution of logarithmically (base 10) transformed maximal otolith radii and body TL of juvenile and silver eels (Francis 1990, 1995) (Fig. 3). For the SPH model, the regression coefficients of the OR-TL relation $\left(\log _{10}\right.$ otolith radius $[\mathrm{mm}]=0.8498 \times \log _{10} \mathrm{TL}[\mathrm{mm}]$ - 2.1031) were used to define the back-calculation equation as follows:

$$
\begin{gathered}
\log _{10} L_{i}=\log _{10} L_{\mathrm{c}}+\log _{10}\left(O_{i} / O_{\mathrm{c}}\right) / b \\
\text { or in non-logarithmic form } L_{i}=\left(O_{i} / O_{\mathrm{c}}\right)^{1 / b} L_{\mathrm{c}}
\end{gathered}
$$

where $L_{i}=$ back-calculated eel body length at age $i$, $L_{\mathrm{c}}=$ eel body length at capture, $b=$ slope from the regression of otolith radius on body $\mathrm{TL}, O_{i}=$ otolith radius at annulus $i$, and $O_{\mathrm{c}}=$ otolith radius from core to edge. For the BPH model, the regression coefficients of the TL-OR relation $\left(\log _{10} \mathrm{TL}[\mathrm{mm}]=1.1533 \times\right.$ $\log _{10}$ radius $[\mathrm{mm}]+2.4700$ ) were used to define the following back-calculation equation:

$$
\begin{aligned}
& \log _{10} L_{i}=\left[\left(c+d \log _{10} O_{i}\right) /\left(c+d \log _{10} O_{c}\right)\right] \log _{10} L_{\mathrm{c}} \\
& \text { or in non-logarithmic form } L_{i}=\left(O_{i} / O_{\mathrm{c}}\right)^{d} L_{\mathrm{c}}
\end{aligned}
$$

where $c=$ intercept and $d=$ slope from the regression of body TL on otolith radius. Mathematically, $L_{i}$ is a geometric estimate and thus was adjusted to an arithmetic estimate following Ricker (1975, p. 275).

Growth analysis. The 'best' back-calculation model for presentation was based on the minimum mean percent difference between the observed mean length-atage and the values estimated by each back-calculation model (SPH, BPH) for Ages 1 to 3 of the silver and juvenile eels. The BPH model, which also had the largest lengths-at-age, was selected. In 2 cases where the final annulus measurement was very close to the otolith edge measurement, the logarithmically transformed and then back-transformed BPH back-calculated length-at-age exceeded the observed length by 0.5 to $0.9 \mathrm{~mm}$. These final back-calculated lengths-at-age were arbitrarily fixed at $1.0 \mathrm{~mm}$ less than the observed length ${ }_{i}$ the potential error in doing so was estimated at less than $0.3 \%$.

Several restrictions were placed on the backcalculated length-at-age estimates for the silver eels. (1) Length-at-age values were logarithmically (base 10) transformed prior to statistical analysis because the variance of the mean lengths-at-age increased significantly (statistical significance was accepted at $\alpha<0.05$ ) with increasing age. Eel growth rates were calculated beginning with the first annulus (Age 1). (2) Although female silver eels to Age 29 and male silver eels to Age 22 were found, the length-at-age and annual growth analyses were restricted to Ages 1 to 13 so as to permit minimal cell sample sizes of at least 7 fish per sex by migratory group (except for male migratory Group 4 with a minimum of 4 fish), after the males and females of migratory Group 3 were omitted from analysis because of small sample size. Oliveira \& McCleave (2002) noted that faster growing yellow eels might metamorphose to silver-phase eels and leave the river at an earlier age than slower growing eels. The age restriction reduces the possibility that slower growing eels might be disproportionately represented at older ages.

The migratory groups were then pooled and recategorized on the basis of whether more than or less than $50 \%$ of the habitat residency after the elver stage occurred in fresh or salt water. The estuarine habitat group was defined as those eels for which more than $50 \%$ of the $\mathrm{Sr}$ : $\mathrm{Ca}$ values were $>4.0 \times 10^{-3}$ along the otolith transect from the first pair of values $<4.0 \times 10^{-3}$; 
the freshwater habitat group had less than $50 \%$ of the $\mathrm{Sr}$ :Ca values $>4.0 \times 10^{-3}$. Thus, 4 sex by habitat groups were defined: $\mathrm{F} 1$ and $\mathrm{M} 1 \mathrm{l}$ = female and male eels with more than $50 \%$ of their habitat residency in freshwater, F2 and M2 = female and male eels with more than $50 \%$ of their habitat residency in estuarine waters. The effect of migration history on length-atage was examined for each sex. Cell sample sizes of 8 or more fish and cell mean lengths with $95 \%$ confidence intervals (CI) less than $\pm 10 \%$ of the mean were achieved by restricting the length-at-age and growth analysis to ages up to $16 \mathrm{yr}$.

Annual growth was estimated as the difference between length at age $t+1$ and at age $t$. Growth rate variances were heterogeneous $\left(F_{\max }\right.$ test $\left.>5.0\right)$ among years for each of the sex-by-habitat residence groups and the standard deviation increased with the mean for individual eel growth rates, so the data were logarithmically transformed (base 10) for statistical analysis. Length-at-age and annual growth rates were approximately normally distributed.

The multiple, sequential measure of otolith radius length, corresponding to different ages, from individual fishes requires the use of repeated-measures procedures because the assumption of independence among observations is not met (Chambers \& Miller 1995, Oliveira \& McCleave 2002). Each year of age provides 1 growth interval for a given fish and all growth intervals were considered equally without regard to an eel's age at capture. A mixed-effects, 3-way repeated measures ANOVA with an autoregressive error structure similar to that of the general model used by Bowen et al. (1992) was used to analyze the longitudinal data on eel length-at-age and annual growth. Age was considered a within-subjects effect, and sex and either migratory group or percent freshwater residency were considered as between-subjects effects. Calculations were made using the mixed-procedure methods of SAS (2001). Single degree of freedom (df) pairwise contrasts between factors (e.g. male freshwater versus female freshwater) were adjusted by sequential Bonferroni corrections as necessary.

Silver eel lengths and ages at migration and mean annual growth rates (over all ages) were analyzed by standard ANOVA and Tukey HSD multiple comparison tests.

The effect magnitude (degree of difference between factors) was estimated as the correlation coefficient $r$ and interpreted as to whether they were large enough to be considered biologically important following Cohen (1988). Effect magnitude $r$ statistics less than 0.1 are regarded as minor, from 0.1 to 0.3 as small, from 0.3 to 0.5 as medium, and from 0.5 to 0.7 as large.

Theoretical growth parameters for American eels grouped by sex and migratory history were estimated by fitting the back-calculated lengths-at-age of individual eels to the 3 parameter von Bertalanffy growth equation (VBGF):

$$
L_{t}=L_{\infty}\left(1-\mathrm{e}^{-K\left[t-t_{0}\right]}\right)+\varepsilon
$$

and the Gompertz growth equation:

$$
L_{t}=L_{\infty} \exp \left(-\frac{1}{k} \mathrm{e}^{-k\left(t-t_{0}\right)}\right)
$$

where $L_{t}=$ length $(\mathrm{mm})$ at age $t_{1} L_{\infty}=$ asymptotic average maximum length, $K=$ growth rate coefficient, $t_{0}=$ theoretical age at which fish length $=0$, and $\varepsilon=$ normal error term. Given that the variances of the lengths-atage increased with increasing age, a loss function was used to adjust for a constant coefficient of variation of the residuals rather than a constant variance (Quinn \& Deriso 1999, Haddon 2001). Parameter estimates and Wald $95 \%$ confidence intervals (estimate $\pm t \times$ asymptotic SE) were made by iterative non-linear least squares using the Gauss-Newton method (S-Plus 2001). Growth curves for each sex and sex by migratory history group were compared for coincidence by the analysis of the residual sum of squares (ARSS) method (Chen et al. 1992, Haddon 2001).

\section{RESULTS}

\section{Back-calculation procedures}

The back-calculated lengths-at-age of the silver eels were slightly larger for the BPH model than for the SPH model, but did not differ significantly because all mean lengths-at-age for each method were well within the respective $95 \%$ CIs for the alternative method. At Age 1, BPH model lengths-at-age were ca. $1.8 \%$ larger for male eels and $1.4 \%$ larger for female eels, and the difference declined to a relatively constant $0.5 \%$ for males and $0.2 \%$ for females by Age 17 . For the juvenile eels, the BPH model lengths-at-age were also larger (by 1.1 to $1.3 \%$ ) than the SPH model values. Relative to the annual mean (60.3 mm over Years 1996 to 2000) and range of elver lengths in the East River (Jessop 2003b), the BPH model values of length at age were judged more realistic. For Ages 1 to 3, the mean length-at-age estimated from juvenile eels and from silver eels did not differ significantly $(F=1.14$, df $=$ $1,253, p=0.29$ ). No significant interaction occurred between age and development stage $(F=1.72$, df $=$ $2,253, \mathrm{p}=0.18)$, indicating that the estimated mean lengths-at-age of juvenile and silver eels was not influenced by development stage. Thus, there was no indication of Lee's phenomenon, where the mean backcalculated lengths at younger ages decrease with the increasing age of the fishes used in back-calculation. 


\section{Growth differences between migratory groups}

A mixed-effects repeated-measures ANOVA of the mean lengths-at-age among migratory Groups 1, 2, and 4 indicated significant effects for sex $(F=6.75, \mathrm{df}=$ $1,51, \mathrm{p}=0.012)$ and age $(F=500.4, \mathrm{df}=13,636, \mathrm{p}<$ $0.0001)$ but not for migratory group $(F=1.09, \mathrm{df}=2,51$, $p=0.34$ ), indicating that the mean length-at-age was similar among migratory groups. The interaction of sex and migratory group was not significant $(F=2.21, \mathrm{df}=$ $2,51, p=0.12$ ) nor were the interactions of age and migratory group and age and sex. Similarly, the effect of migratory group on annual growth was not significant $(F=2.24, \mathrm{df}=2,51, \mathrm{p}=0.12)$. Thus, the migratory groups were pooled and the length-at-age and annual growth by estuarine (100\% - freshwater residency \%) and freshwater contingents was analyzed. For the estuarine-residency contingent, the modal percent of estuarine residency was $73.1 \%$ (range 52.0 to $90.9 \%$ ) for males and $85.4 \%$ (range 56.2 to $93.2 \%$ ) for females, while for the freshwater-resident contingent the modal freshwater residency was $94.3 \%$ (range 51.0 to $100 \%$ ) for males and $98.4 \%$ (range 56.0 to $100 \%$ ) for females.

\section{Length differences between sexes and habitat residence groups}

A mixed-effects repeated-measures ANOVA indicated significant effects on silver eel length by sex, habitat residence and age (Table 2). Interactions between sex and habitat residence and age and habitat residence were not significant. The interaction between sex and age was significant, indicating that lengths-at-age differed between sexes (Fig. 4). Mean lengths-at-age for female silver eels were significantly larger than for males, with significant differences between sexes beginning at Age 6. At Age 16, female silver eels with a history of estuarine residence $(436.4 \mathrm{~mm})$ were significantly longer in mean length

Table 2. Anguilla rostrata. Mixed-effects ANOVA results for the effects of sex, freshwater residency $(\% \mathrm{FW})$, and age on the length-at-age of silver American eels from the East River, Nova Scotia

\begin{tabular}{|lccc|}
\hline Effect & df & $F$ & $p$ \\
\hline Sex & 1.57 & 18.86 & $<0.0001$ \\
$\%$ FW & 1.57 & 8.64 & 0.005 \\
Sex $\times$ FW & 1.57 & 0.02 & 0.90 \\
Age & 15.781 & 636.14 & $<0.0001$ \\
Age $\times$ Sex & 15.781 & 2.55 & 0.001 \\
Age $\times \%$ FW & 15.781 & 1.29 & 0.20 \\
Age $\times$ Sex $\times \%$ FW & 15.781 & 0.81 & 0.67 \\
\hline
\end{tabular}

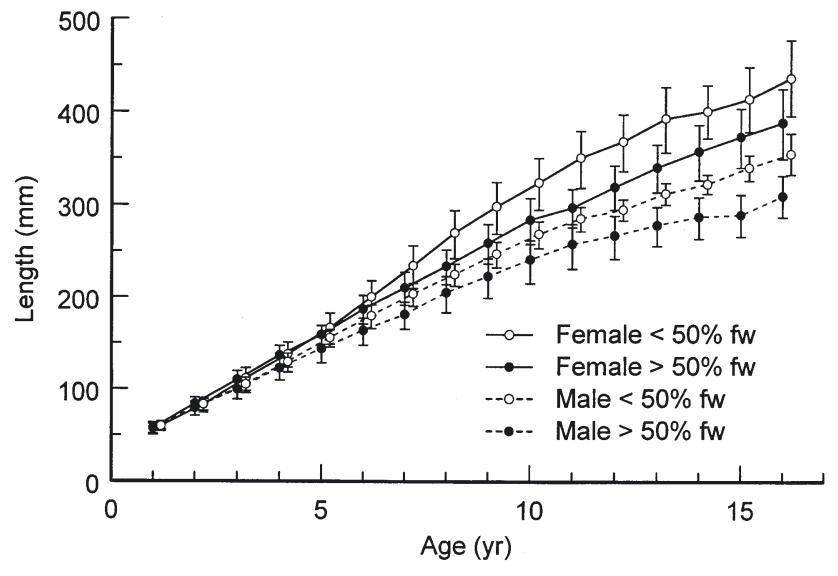

Fig. 4. Anguilla rostrata. Mean back-calculated lengths-atage $(\mathrm{mm})$ with $95 \%$ CIs, by sex and migratory history, of silver American eels from the East River, Nova Scotia. fw = freshwater residence

than were female eels with a freshwater history $(388.2 \mathrm{~mm})$, as were male silver eels (354.6 vs $309.3 \mathrm{~mm}$ ) (Fig. 4).

\section{Growth differences between sexes and habitat residence groups}

A mixed-effects repeated-measures ANOVA indicated significant effects on silver eel annual growth by sex, habitat residence and age, with no significant interactions among factors (Table 3, Fig. 5). To Age 16, female eel annual growth was higher than for males, and estuarine residents grew more rapidly than did freshwater residents. Annual growth rate varied with age, tending to decline with increasing age.

The mean annual growth (all ages) of individual female silver eels averaged $25.2 \mathrm{~mm} \mathrm{yr}^{-1}\left(25.4 \mathrm{~mm} \mathrm{yr}^{-1}\right.$ to Age 16) and $20.5 \mathrm{~mm} \mathrm{yr}^{-1}$ (20.7 $\mathrm{mm} \mathrm{yr}^{-1}$ to Age 16) for male silver eels (Table 4). Female silver eels with a

Table 3. Anguilla rostrata. Mixed effects ANOVA results for the effects of sex, freshwater residency $(\% \mathrm{FW})$, and age on the annual growth of silver American eels from the East River, Nova Scotia

\begin{tabular}{|lcrc|}
\hline Effect & df & $F$ & $p$ \\
\hline Sex & 1.57 & 36.56 & $<0.001$ \\
$\%$ FW & 1.57 & 11.14 & $<0.002$ \\
Sex $\times$ FW & 1.57 & 0.05 & 0.82 \\
Age & 14.724 & 636.14 & $<0.001$ \\
Age $\times$ Sex & 14.724 & 1.06 & 0.39 \\
Age $\times \%$ FW & 14.724 & 0.80 & 0.66 \\
Age $\times$ Sex $\times \%$ FW & 14.724 & 0.85 & 0.61 \\
\hline
\end{tabular}




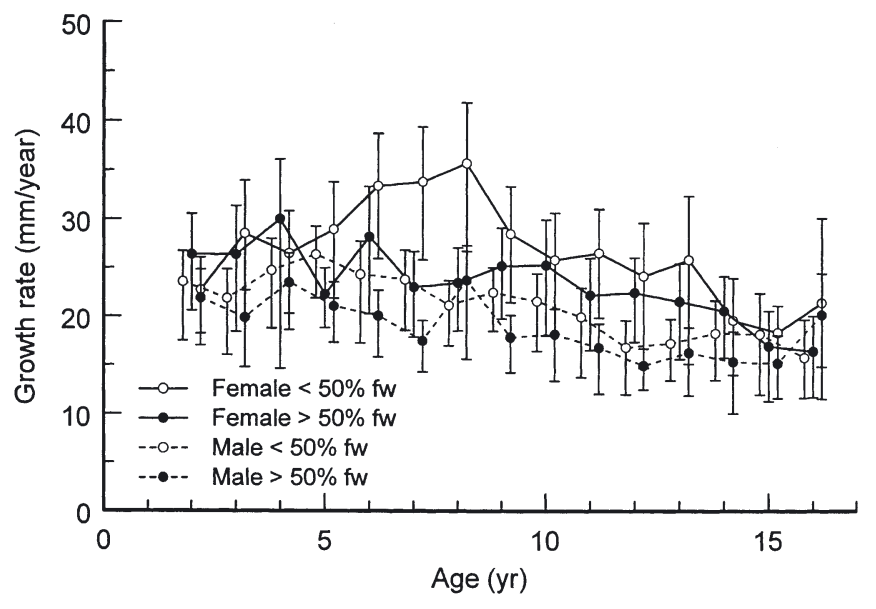

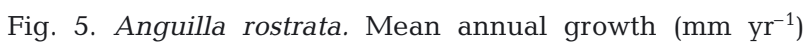
with $95 \%$ CIs, by sex and migratory history, of silver American eels from the East River, Nova Scotia. fw = freshwater residence

history of estuarine residence had a significantly $(F=$ $6.88, \mathrm{df}=1,24, \mathrm{p}=0.015$ ) higher mean annual growth

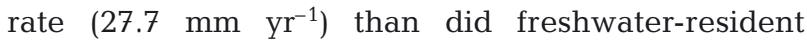
females $\left(22.7 \mathrm{~mm} \mathrm{yr}^{-1}\right)$, as did male silver eels $(21.8 \mathrm{vs}$ $19.2 \mathrm{~mm} \mathrm{yr}^{-1} ; F=4.59, \mathrm{df}=1,33, \mathrm{p}=0.040$ ).

The significance of the difference between parameters of the von Bertalanffy growth curves between sexes and sex-by-habitat residence groups may generally be evaluated by the degree of non-overlap of the $95 \%$ CI (Table 5). Thus, where the $95 \%$ CI for parameter values do not overlap, the values differ significantly; where a parameter value for 1 or both groups is included within the $95 \%$ CI of the other group, no significant difference exists, but where the $95 \%$ CI for each parameter simply overlap, no definitive conclusion can be made. For example, the average maximum length $\left(L_{\infty}\right)$ was significantly larger for females $(862.8 \mathrm{~mm})$ than for males $(491.5 \mathrm{~mm})$, and the growth coefficient $(K)$ was smaller for females

Table 4. Anguilla rostrata. Mean annual growth $\left(\mathrm{mm} \mathrm{yr}^{-1}\right)$, with sample size (N), $95 \% \mathrm{CI}$, and range, by sex and habitat residence, of silver American eels from the East River, Chester, Nova Scotia. $>50 \%$ fw $=$ freshwater habitat residence, $<50 \% \mathrm{fw}=$ estuarine habitat residence

\begin{tabular}{|lcccc|}
\hline Group & Mean & $\mathrm{N}$ & $\pm 95 \% \mathrm{CI}$ & Range \\
\hline Male & 20.5 & 35 & $19.0-21.4$ & $13.9-29.0$ \\
Female & 25.2 & 26 & $22.6-26.8$ & $14.9-38.0$ \\
$>50 \% \mathrm{fw}$ & 20.7 & 30 & $18.8-21.8$ & $13.9-32.6$ \\
$<50 \% \mathrm{fw}$ & 23.4 & 31 & $21.2-24.7$ & $17.4-38.0$ \\
Male, $>50 \% \mathrm{fw}$ & 19.2 & 17 & $17.4-20.6$ & $15.7-29.0$ \\
Male, $<50 \% \mathrm{fw}$ & 21.8 & 18 & $19.8-23.3$ & $13.9-28.8$ \\
Female, $>50 \% \mathrm{fw}$ & 22.7 & 13 & $19.5-25.3$ & $14.9-32.6$ \\
Female, $<50 \% \mathrm{fw}$ & 27.7 & 13 & $24.6-30.3$ & $21.0-38.0$ \\
\hline
\end{tabular}

(0.040) than for males (0.066), but no conclusion can be made about the significance of the difference between the values of $t_{0}$, the hypothetical age at which eels have zero length, for females $(-0.658)$ and males (-0.819). For both males and females, $L_{\infty}$ was significantly larger and $K$ was smaller, but not necessarily significantly so, for eels with an estuarine history than for eels with a freshwater history. The ARSS analysis indicated that the VBGF curves of male and female eels differed significantly $(F=126.3$, df $=$ $3,989, \mathrm{p}<0.0001)$ as did those for males $(F=34.1, \mathrm{df}=$ $3,535, \mathrm{p}<0.0001)$ and females $(F=42.5, \mathrm{df}=3,448$, $\mathrm{p}<0.0001$ ) of estuarine and freshwater habitat histories. Consideration of the increased variability in length-at-age with increasing age resulted in VBGF parameter estimates for the various growth curves that were $5.0 \%$ (range -4.5 to $10.0 \%$ ) higher for $L_{\infty}$ $7.6 \%$ (range -7.1 to $17.4 \%$ ) lower for $K$, and $21.1 \%$ (range -3.9 to $47.3 \%$ ) higher for $t_{0}$ than when a constant variance was assumed.

\section{Lengths and ages at migration}

Silver eel lengths at migration were significantly influenced by sex $(F=63.8, \mathrm{df}=1,57, \mathrm{p}<0.0001)$ and habitat residence history $(F=4.81, \mathrm{df}=1,57, \mathrm{p}=0.032)$, with no significant interaction between factors $(F=$ 2.98, $\mathrm{df}=1,57, \mathrm{p}=0.09$ ). At migration, male silver eels (mean length $354.4 \mathrm{~mm}$ ) were significantly smaller than were female eels (mean length $470.4 \mathrm{~mm}$ ) (Table 1). Eels (sexes combined) with a history of freshwater residency were significantly smaller in mean length $(390.4 \mathrm{~mm})$ than were eels with an estuarine history $(416.9 \mathrm{~mm})$. Female silver eels with an estuarine residence history were longer $(498.9 \mathrm{~mm})$, but not significantly so $(\mathrm{p}=0.058$, Tukey HSD test), than females with a freshwater history $(441.9 \mathrm{~mm})$ although the effect size $r=0.31$ of the difference between means was moderate. Male silver eels of different habitat residence histories did not differ significantly in length (estuarine $357.8 \mathrm{~mm}$, freshwater $351.0 \mathrm{~mm}$; $\mathrm{p}=0.98$, Tukey HSD test).

Silver eel age at migration was not significantly influenced by $\operatorname{sex}(F=3.94$, df $=1,57, \mathrm{p}=0.052)$, although the non-significance was marginal, or by habitat residence history $(F=2.40, \mathrm{df}=1,57, \mathrm{p}=0.13)$, and the interaction between sex and habitat history was not significant $(F=0.10, \mathrm{df}=1,57, \mathrm{p}=0.75)$. At migration, females averaged $17.5 \mathrm{yr}$ old and males averaged $15.5 \mathrm{yr}$ old. The age at which silver eels of both sexes began downstream migration was negatively correlated with the mean annual growth rate (males: $r=-0.92, \mathrm{n}=35, \mathrm{p}<0.001$; females: $r=$ $-0.66, \mathrm{n}=26, \mathrm{p}<0.001$ ). 
Table 5. Anguilla rostrata. Parameter estimates and Wald 95\% CI for the von Bertalanffy growth equation, by sex and sex by habitat residence, for silver American eels from the East River, Chester, Nova Scotia. $>50 \%$ fw $=$ freshwater habitat residence, $<50 \% \mathrm{fw}=$ estuarine habitat residence

\begin{tabular}{|c|c|c|c|c|c|c|c|c|}
\hline Group & $\mathrm{N}$ & $L_{\infty}$ & $95 \% \mathrm{CI}$ & $K$ & $95 \% \mathrm{CI}$ & $t_{0}$ & $95 \% \mathrm{CI}$ & $\mathrm{r}^{2}$ \\
\hline Male $>50 \%$ fw & 17 & 463.7 & $398.3-529.0$ & 0.066 & $0.051-0.084$ & -0.917 & -1.294 to -0.541 & 0.91 \\
\hline Male $<50 \%$ fw & 18 & 656.8 & $531.9-781.6$ & 0.047 & $0.035-0.061$ & -0.965 & -1.241 to -0.688 & 0.96 \\
\hline Female $>50 \%$ fw & 13 & 560.5 & $496.4-624.6$ & 0.068 & $0.055-0.083$ & -0.434 & -0.731 to 0.136 & 0.93 \\
\hline Female $<50 \%$ fw & 13 & 1241.3 & $957.5-1525.2$ & 0.027 & $0.020-0.037$ & -0.672 & -0.957 to 0.386 & 0.96 \\
\hline Male total & 35 & 491.5 & $441.2-541.8$ & 0.066 & $0.055-0.078$ & -0.819 & -1.054 to -0.583 & 0.92 \\
\hline Female total & 26 & 862.8 & $736.1-989.5$ & 0.040 & $0.032-0.049$ & -0.658 & -0.915 to 0.401 & 0.93 \\
\hline
\end{tabular}

\section{DISCUSSION}

\section{Back-calculation procedures}

The OR-TL relation differs between the elver and the older yellow and silver eel stages of the American eel. Otoliths may change shape as they grow through ontogenesis (Secor \& Dean 1989, Hare \& Cowen 1995). The eel otolith changes from roughly circular in elvers to ovate in older eels as the rostrum and postrostrum become more pronounced (Härkönen 1986, Doering \& Ludwig 1990). The practice of fixing the origin of the regression of otolith radius on eel length at the mean length of glass eels upon entry to freshwater (e.g. Poole \& Reynolds 1996a,b, Graynoth 1999, and Jellyman 2001) may not be appropriate for American eels, because the accuracy of estimated lengths-at-age, particularly younger ages, is directly related to the fit of the OR-TL relation and the OR-TL model may be as important as selecting the appropriate backcalculation model (Schirripa 2002). When the OR-TL relation is tight, different proportional back-calculation methods show little difference in results (Pierce et al. 1996), as was observed in this study. The method used by Poole \& Reynolds (1996a,b) underestimated the annual growth (both sexes combined) of eels from the East River between Ages 1 and 2 by $14 \%$, relative to the BPH method. The difference decreased with increasing age, up to Age 6 to 7 , after which the growth was progressively overestimated, becoming different by $9 \%$ by Age 16 to 17 . When a sufficient size range of eels is available, particularly including smaller eels, the relationship between otolith radius and body length is curvilinear (Graynoth 1999, Oliveira \& McCleave 2002) when measured along the transverse plane and may be either curvilinear (this study) or linear (Fernandez-Delgado et al. 1989) when measured along the sagittal plane. Logarithmic transformation to linearize the otolith-fish length relationship for use in a proportional back-calculation model or the use of a non-linear back-calculation model may be appropriate.
Although the expectation is that otolith growth is proportional to body growth throughout a fish's life (Campana 1990), otolith growth is not always proportionally coupled to somatic growth for European eels Anguilla anguilla (Holmgren 1996) or other species (Secor \& Dean 1989, Wright 1991, Bradford \& Geen 1992, Mosegaard et al. 1998). However, over longer growth periods the assumption of constant otolith growth scaling resulted in non-significant bias when a proportional back-calculation method was used (Holmgren 1996).

The high variability in length-at-age among individual eels and in annual growth increments within eels observed for the East River is typical of eels in other rivers (Panfili et al. 1994, Poole \& Reynolds 1996b, Oliveira \& McCleave 2002). Some of this variability is due to the difficulties of aging eels using polished otoliths (Panfili \& Ximenes 1992), particularly older eels where annuli may be closely spaced at the otolith edge, and may result in underestimating the age and, thus, overestimating the growth rate of some eels.

The inability to sample the entire run of silver eels creates potential biases. The silver eels sampled at the start of the run may have been smaller, younger and faster growing than the run average, particularly the females (Jessop 1987), which could result in overestimated mean growth rates. Relative, rather than absolute, comparisons may be less affected as are issues pertaining to the growth of individual eels.

\section{Growth differences between sexes}

Female anguillid eels typically mature sexually at larger sizes and older ages than do male eels (Helfman et al. 1987, Vøllestad 1992, Panfili et al. 1994, Poole \& Reynolds 1996b, Holmgren et al. 1997, Oliveira 1999, Tzeng et al. 2000a, Oliveira \& McCleave 2002). In the East River, female silver eels were larger than males, but the age at migration was marginally not significantly different between males and females. Significant differences in length-at-age between males and 
females began at Age 6, an age at which Oliveira \& McCleave (2000) found that over $40 \%$ of American eels were sexually differentiated (growth rates to Age 6 were comparable for each sex between studies).

The VBGF growth model has often been used for anguillid eels (Moriarty 1983, Fernández-Delgado 1989, Poole \& Reynolds 1996a,b, Tzeng et al. 2000a), but it is only one of several growth models (Quinn \& Deriso 1999). A comparison of the VBGF and Gompertz asymptotic growth models indicated that the VBGF model best fitted the data, particularly when the increased variability in length-at-age with increasing age was considered. The fitting of any growth curve to eel lengths-at-age may be biased at older ages by the departure of faster growing, earlier maturing eels, so that older age cohorts consist of slower growing fish. The use of back-calculated lengths-at-age from individual silver eels rather than mean lengths-at-age from a sample of eels of all maturity stages may reduce this problem.

Female growth rates are usually higher than for males (Panfili et al. 1994, Oliveira 1999, Svedäng 1999, Oliveira \& McCleave 2002, Tzeng et al. 2003, this study), but some eel stocks show higher growth rates for males than for females (Poole \& Reynolds 1996b, Holmgren et al. 1997). Despite a higher $L_{\infty}$ and lower $K$ value for females than for males, as noted also by Poole \& Reynolds (1996a,b) and Tzeng et al. (2000), the observed average annual growth of females was higher than for males. Thus, although males may approach their theoretical maximum mean length more quickly than females, their observed annual growth rates are less than for females. A negative relation between observed growth rate and age at migration appears common (Vøllestad 1992, Svedäng et al. 1996, Jellyman 2001, Oliveira \& McCleave 2002, this study). Given that faster growing eels begin maturation and downstream migration at younger ages than do slower growing eels, and that both sexes tend to migrate at lengths less than their theoretical average maximum (Poole \& Reynolds 1996b, Svedäng et al. 1996, Tzeng et al. 2000), the use of $K$ as an indicator of growth rate is not equivalent to the use of observed annual growth rates in the interpretation of growth because they examine different aspects of growth (Wang \& Milton 2000).

The sexual maturation of male eels is consistent with a time-minimizing life-history strategy (Helfman et al. 1987, Vøllestad 1992, Oliveira 1999), but the strategy for female eels is less clear (Svedäng et al. 1996, Holmgren et al. 1997, Oliveira 1999, Jellyman 2001). Oliveira (1999) hypothesized that female age and size at maturation may be optimized over a continuum between a time-minimizing strategy and a size-maximizing strategy according to habitat conditions, so as to reach an optimal size and body condition for migration, relative to the habitat, in minimal time. Jellyman (2001) provides further evidence in support of this hypothesis, as do Oliveira \& McCleave (2002), who also conclude that eels have evolved growth strategies and rates intrinsic to each sex that enable them to adapt successfully to a wide range of habitats.

\section{Growth differences between migratory contingents}

Annual growth rates for eels are influenced by environmental conditions such as habitat productivity, seasonal water temperatures, and the duration of the growth season that vary geographically, particularly with latitude (Tesch 1977, Fernandez-Delgado et al. 1989, Vøllestad 1992, Panfili et al. 1994). The low-pH, low-productivity waters of the East River, resulted in a mean annual growth rate of $20.5 \mathrm{~mm} \mathrm{yr}^{-1}$ for individual male silver eels and $25.2 \mathrm{~mm} \mathrm{yr}^{-1}$ for female silver eels. In Maine at a latitude similar to the East River, mean annual growth rates were $26.1 \mathrm{~mm} \mathrm{yr}^{-1}$ for male yellow eels to Age 11 and $30.9 \mathrm{~mm} \mathrm{yr}^{-1}$ to Age 14 for females (recalculated from Oliveira \& McCleave 2002), and in a more southern Rhode Island river, mean growth was $30.9 \mathrm{~mm} \mathrm{yr}^{-1}$ for male silver eels and $39.8 \mathrm{~mm} \mathrm{yr}^{-1}$ for female silver eels (Oliveira 1999). The mean annual growth of female silver eels was estimated at $41 \mathrm{~mm}$ $\mathrm{yr}^{-1}$ in the Medway River and at $51 \mathrm{~mm} \mathrm{yr}^{-1}$ in the LaHave River of Nova Scotia (Jessop 1987), both of which have higher pHs than the East River (Watt et al. 1995). A mean annual growth of $20.8 \mathrm{~mm} \mathrm{yr}^{-1}$ was found for silver Anguilla anguilla from a low $\mathrm{pH}$, oligotrophic lake in Ireland (Poole \& Reynolds 1996b). Optimal growth for European eels occurs at water temperatures between 22 and $26.5^{\circ} \mathrm{C}$ (Panfili et al. 1994) and at similar temperatures for American eel elvers (Peterson \& Martin-Robichaud 1994) and, probably, juvenile eels. In the East River, such water temperatures occur in the river only for a few weeks, at most, during July and August and rarely, if ever, in the associated estuary (Jessop et al. 2002, Jessop 2003c).

Fish migration between marine and freshwater habitats may generally be explained by the difference in food productivity, and catadromy occurs primarily in tropical latitudes where freshwater productivity exceeds marine productivity (Gross 1987, Gross et al. 1988). Consequently, temperate-zone eels inhabiting a more productive estuarine area would be expected to show higher growth rates, as was observed in this study. However, Tzeng et al. (2003) also observed higher growth in estuarine-resident Japanese eels from semi-tropical areas such as Taiwan and southern China and from the more temperate southern Japan. More generally, Oliveira \& McCleave (2000) hypothe- 
sized that growth (environmental) conditions are the primary factor influencing the size and age of eels at migration, and further that habitats with similar environmental conditions will produce eels with similar traits and life-history styles. Consequently, different habitats will produce eels with different traits and lifehistory styles, evidence for which is found in the latitudinal clines in biological factors such as decreasing growth rate and increasing age and size at migration (Helfman et al. 1987, Vøllestad 1992, Oliveira 1999), more rapid growth in estuarine than in freshwater habitats (Helfman et al. 1984, Fernández-Delgado et al. 1989) and the occurrence and proportion of eels that migrate between fresh- and saltwaters (Tsukamoto \& Arai 2001, Jessop et al. 2002).

Silver-stage American eels of both sexes that had primarily estuarine residence histories grew more rapidly and attained longer lengths-at-age and at migration than did eels with a primarily freshwater history. These results, and the observation by Jessop et al. (2002) that $64 \%$ of silver eels sampled from the East River showed evidence of migrating periodically between fresh and marine waters, indirectly support the hypothesis that sea residency by anguillid eels should occur more frequently at higher latitudes where freshwater productivity is lower than in adjacent coastal areas, as eels seek to maximize the relative benefits of each habitat type (Gross 1987, Tsukamoto \& Arai 2001, Tsukamoto et al. 2002). However, Morrison et al. (2003) found that $65 \%$ of yellow eels in the lower portion of the more southerly Hudson River, New York, had migrated from fresh to estuarine waters, suggesting that perhaps factors other than latitude influence the relation between the frequency of migration and latitude. The reduction of mortality risk by changing habitats, particularly at younger ages (Mann 2000), but also for larger eels that have relatively slow growth and delayed maturity, may also be important, as may relative eel density in lower stream reaches.

American eels occur in continental North America to ca. $54^{\circ} \mathrm{N}$ latitude, Asian eels occur to ca. $45^{\circ} \mathrm{N}$ latitude while European eels occur to $71^{\circ} \mathrm{N}$ latitude in northern Norway and the White Sea coast of Russia (Tesch 1977). The northern distributions of temperate-zone Anguilla are influenced largely by the effects of northern flowing tropical and southward flowing subarctic coastal currents, such as the southward flowing Labrador and northward flowing Gulf Stream currents along the eastern coast of North America and the southward flowing Kurile and Oyashio currents and northward flowing Kuroshio and Tsushima currents off the eastern coast of Asia (Tesch 1977, Longhurst 1998). These currents differ in pattern from the eastward and northward flowing North Atlantic and Norwegian Coastal currents that warm the European Atlantic coast.
Anguillid eels have not yet been identified as having the antifreeze glycopeptides or the antifreeze proteins of other species of Arctic and Antarctic fishes (Fletcher et al. 1998) that would prevent their freezing at temperatures below $-0.7^{\circ} \mathrm{C}$ when seawater may reach temperatures of $-1.9^{\circ} \mathrm{C}$ before freezing. The $-1^{\circ} \mathrm{C}$ isotherm of winter coastal water temperatures and the extent of coastal ice formation and their effects on over-winter survival in estuarine and coastal areas may set a northern limit on the latitude beyond which increased coastal residence or freshwater/estuarine migratory behaviour might occur. At the northern extremes of the range of American and Japanese eels, an extended period of coastal ice conditions and low coastal water temperatures create a relatively short period suitable for eel growth, while the Atlantic coast of northern Europe remains above $3.3^{\circ} \mathrm{C}$ south of ca. $68^{\circ} \mathrm{N}$ latitude, although the Baltic Sea north of ca. $55^{\circ} \mathrm{N}$ develops extensive winter ice cover (US Naval Oceanographic Office 1967, Longhurst 1998, Canadian Ice Service 2001). Thus, the northern extent of estuarine and coastal residence and periodic migration between fresh and estuarine waters may be greater in Europe, relative to North America and Asia, because of the more favorable coastal environmental conditions.

Approximately $63 \%$ of the estimated available eel habitat in Europe is in coastal and estuarine waters, of which $93 \%$ occurs north of France, primarily in Scandinavia and the Baltic Sea (Moriarty \& Dekker 1997). About $67 \%$ of the European catch of yellow and silver eels occurs north of France, with ca. $50 \%$ of the catch occurring in saline waters. Few European eel fisheries occur north of ca. $60^{\circ} \mathrm{N}$ and eel abundance and productivity evidently declines as habitat suitability declines. The relative abundance of coastal and estuarine resident eels in North America is unknown (Haro et al. 2000), but they occur from the southern United States (Hansen \& Eversole 1984, Helfman et al. 1984), if not further south, to the Maritime Provinces of Canada (Smith \& Saunders 1955, Eales 1968, Medcof 1969) and even the Atlantic coast of Newfoundland, if brackish water coastal ponds are considered (Gray \& Andrews 1971). Japanese eels with histories of sea residence and of freshwater-estuarine migration occur from the semi-tropical coastal and estuarine waters of Taiwan and southern China to the more temperate waters of southern Japan (Tsukamoto \& Arai 2001, Tzeng et al. 2002, 2003) and northern Japan (Arai et al. 2003), almost to the northern limit of their range (Tesch 1977), but their relative abundance is unknown (Tsukamoto \& Arai 2001). The proportion of sea resident eels may increase with increasing latitude but the proportion of migratory eels shows little difference to near $35^{\circ} \mathrm{N}$ latitude (Tzeng et al. 2003). About 60 to $80 \%$ of Japanese eels in coastal areas between 22 and 
$35^{\circ} \mathrm{N}$ latitude may be migratory between freshwater and estuary (Tsukamoto \& Arai 2001, Tzeng et al. 2002, 2003), but at ca. $40^{\circ} \mathrm{N}$ the density and proportion of migratory fish may be lower (Arai et al. 2003). Differences in relative productivity or habitat suitability between the rivers and estuaries of mountainous Taiwan and the coastal plains of southern China may also occur (e.g. Tzeng et al. 2002), perhaps related to the relative inflow of freshwater and stream geomorphology (Mann 2000). Thus, the coastal interplay of northward-flowing tropical currents and southward flowing subarctic currents and their effect on estuarine conditions and productivity and other factors may modify a strictly latitudinal approach to the marine/freshwater distribution of temperate zone anguillid eels.

It has become increasingly evident that American, European and Japanese eels, if not other anguillids such as Anguilla marmorata (Shiao et al. 2003), have complex, geographically varied, migratory histories which can affect their growth, age and size at sexual maturation, and which require consideration in their stock management. Further research, particularly at the extremes of their geographic distributions, is needed to clarify the residence patterns of northern hemisphere anguillid eels relative to the hypothesis of a latitudinal cline in the abundance of marine resident eels.

Acknowledgements. We thank K. Marshall, J. Orser, D. Schnare, D. Sutherland and S. Ratelle for their assistance in various aspects of the collection and processing of the eel samples, W. Blanchard and C. Harvie for statistical assistance and D. Cairns for reviewing the manuscript. The National Science Council, Republic of China, provided financial support for the otolith analysis through Grant Number NSC89-2313-B002-077.

\section{LITERATURE CITED}

Arai T, Kotake A, Ohji M, Miller MJ, Tsukamoto K, Miyazaki N (2003) Occurrence of sea eels of Anguilla japonica along the Sanriku coast of Japan. Ichthyol Res 50:78-81

ASMFC (Atlantic States Marine Fisheries Commission) (2000) Interstate fishery management plan for the American eel. ASMFC Fishery Management Rep No 36. ASMFC, Washington, DC

Avise JC, Helfman GS, Saunders NC, Hales LS (1986) Mitochondrial DNA differentiation in North Atlantic eels: population genetic consequences of an unusual life history pattern. Proc Natl Acad Sci USA 83:4350-4354

Bath GE, Thorrold SR, Jones CM, Campana SE, McLaren JW, Lam JWH (2000) Strontium and barium uptake in aragonitic otoliths of marine fish. Geochim Cosmochim Acta 64: 1705-1714

Bertin L (1956) Eels: a biological study. Cleaver-Hume Press, London

Bouillon DR, Haedrich RL (1985) Growth of silver eels (Anguilla rostrata) in two areas of Newfoundland. J NW Atl Fish Sci 6:95-100

Bowen WD, Stobo WT, Smith SJ (1992) Mass changes of grey seal Halichoerus grypus pups on Sable Island: differential maternal investment reconsidered. J Zool Lond 227: $607-622$

Bradford MJ, Geen GH (1992) Growth estimates from otolith increment widths of juvenile Chinook salmon (Oncorhynchus tshawytscha) reared in changing environments. J Fish Biol 41:825-832

Campana SE (1990) How reliable are growth back-calculations based on otoliths? Can J Fish Aquat Sci 47:2219-2227

Campana SE (1999) Chemistry and composition of fish otoliths: pathways, mechanisms and applications. Mar Ecol Prog Ser 188:263-297

Canadian Ice Service (2001) Sea ice climate atlas, East coast of Canada 1971-2000. Envir Canada, Ottawa

Chambers RC, Miller TJ (1995) Evaluating fish growth by means of otolith increment analysis: special properties of individual-level longitudinal data. In: Secor DH, Dean JM, Campana SE (eds) Recent developments in fish otolith research. The Belle W. Baruch Library in Marine Science No 19. University of South Carolina Press, Columbia, SC, p 155-175

Chen Y, Jackson DA, Harvey HH (1992) A comparison of von Bertalanffy and polynomial functions in modeling fish growth data. Can J Fish Aquat Sci 49:1288-1235

Cohen J (1988) Statistical power analysis for the behavioral sciences, 2nd edn. Lawrence Erlbaum Associates, Hillsdale

Dekker W (2000) Impact of yellow eel exploitation on spawner production in Lake Ijsselmeer, the Netherlands. Dana 12:17-32

Dekker W et al. (2003) Quebec declaration of concern. Fisheries 28:28-30

Doering P, Ludwig J (1990) Shape analysis of otoliths - a tool for indirect ageing of eel, Anguilla anguilla (L.)? Int Rev Hydrobiol 75:737-743

Eales JG (1968) The eel fisheries of eastern Canada. Fish Res Board Can Bull 166

Elsdon TS, Gillanders BM (2002) Interactive effects of temperature and salinity on otolith chemistry: challenges for determining environmental histories of fish. Can J Fish Aquat Sci 59:1796-1808

Fernández-Delgado C, Hernando JA, Herrera M, Bellido M (1989) Age and growth of yellow eels, Anguilla anguilla, in the estuary of the Guadalquivir River (southwest Spain). J Fish Biol 34:561-570

Fletcher GL, Goddard SV, Davies PL, Gong Z, Ewart KV, Hew CL (1998) New insights into fish antifreeze proteins: physiological significance and molecular regulation. In: Poertner HO, Playle RC (eds) Cold ocean physiology. Soc Exp Biol Sem Ser No 66, Society of Experimental Biology, p 239-265

Francis RICC (1990) Back-calculation of fish length: a critical review. J Fish Biol 36:883-902

Francis RICC (1995) The analysis of otolith data-a mathematician's perspective (what, precisely, is your model?). In: Secor DH, Dean JM, Campana SE (eds) Recent developments in fish otolith research. The Belle W. Baruch Library in Marine Science No 19. University of South Carolina Press, Columbia, SC, p 81-94

Gray RW, Andrews CW (1971) Age and growth of the American eel (Anguilla rostrata) (LeSueur) in Newfoundland waters. Can J Zool 49:121-128

Graynoth E (1999) Improved otolith preparation, ageing and back-calculation techniques for New Zealand freshwater eels. Fish Res 42:137-146

Gross MR (1987) Evolution of diadromy in fishes. Am Fish Soc Symp 1:14-25 
Gross MR, Coleman RM, McDowall RM (1988) Aquatic productivity and the evolution of diadromous fish migration. Science 239:1291-1293

Haddon M (2001) Modelling and quantitative methods in fisheries. Chapman \& Hall/CRC, Boca Raton, FL

Hansen RA, Eversole RG (1984) Age, growth, and sex ratio of American eels in brackish water portions of a South Carolina river. Trans Am Fish Soc 113:744-749

Hare JA, Cowen RK (1995) Effect of age, growth rate, and ontogeny on the otolith size-fish size relationship in bluefish, Pomatomus saltatrix, and the implications for back-calculation of size in fish early life history stages. Can J Fish Aquat Sci 52:1909-1922

Härkönen T (1986) Guide to the otoliths of the bony fishes of the northeast Atlantic. Danbiu ApS, Biological Consultants, Hellerup

Haro A, Richkus W, Whalen K, Hoar A, Busch WD, Lary S, Brush T, Dixon D (2000) Population decline of the American eel: implications for research and management. Fisheries 25(9):7-16

Helfman GS, Bozeman EL, Brothers EB (1984) Size, age, and sex of American eels in a Georgia river. Trans Am Fish Soc 113:132-141

Helfman GS, Facey DE, Hales LS Jr, Bozeman EL Jr (1987) Reproductive ecology of the American eel. Am Fish Soc Symp 1:42-56

Holmgren K (1996) Otolith growth scaling of the eel, Anguilla anguilla (L.), and back-calculation errors revealed from alizarin labeled otoliths. Nordic J Freshw Res 72:71-79

Holmgren K, Wickström H, Clevestam P (1997) Sex-related growth of European eel, Anguilla anguilla, with focus on median silver eel age. Can J Fish Aquat Sci 54:2775-2781

ICES (International Council for the Exploration of the Sea) (2001) Report of the ICES/EIFAC Working Group on Eels. ICES CM2001/ACFM: 03

ICES (International Council for the Exploration of the Sea) (2003) Report of the ICES/EIFAC Working Group on Eels. ICES CM2003/ACFM: 06

Jellyman D (2001) The influence of growth rate on the size of migrating female eels in Lake Ellesmere, New Zealand. J Fish Biol 58:725-736

Jessop BM (1987) Migrating American eels in Nova Scotia. Trans Am Fish Soc 116:161-170

Jessop BM (2000) Estimates of population size and instream mortality rate of American eel elvers in a Nova Scotia river. Trans Am Fish Soc 129:514-526

Jessop BM (2003a) The run size and biological characteristics of American eel elvers in the East River, Chester, Nova Scotia, 2000. Can Tech Rep Fish Aquat Sci No 2444

Jessop BM (2003b) Annual and seasonal variability in the size and biological characteristics of the runs of American eel elvers to two Nova Scotia rivers. In: Dixon DA (ed) Biology, management, and protection of catadromous eels. Am Fish Soc Symp 33:17-36

Jessop BM (2003c) Annual variability in the effects of water temperature, discharge, and tidal stage on the migration of American eel elvers from estuary to river. In: Dixon DA (ed) Biology, management, and protection of catadromous eels. Am Fish Soc Symp 33:3-16

Jessop BM, Shiao JC, Iizuka Y, Tzeng WN (2002) Migratory behaviour and habitat use by American eels Anguilla rostrata as revealed by otolith microchemistry. Mar Ecol Prog Ser 233:217-229

Kawakami Y, Mochioka N, Morishita K, Tajima T, Nakagawa H, Toh H, Nakazono A (1998) Factors influencing otolith strontium/calcium ratios in Anguilla japonica elvers. Environ Biol Fish 52:299-303
Krueger WH, Oliveira K (1997) Sex, size, and gonad morphology of silver American eels Anguilla rostrata. Copeia 1997:415-420

Longhurst A (1998) Ecological geography of the sea. Academic Press, San Diego

Mann KH (2000) Ecology of coastal waters with implications for management, 2nd edn. Blackwell Science, Malden

Medcof JC (1969) Fishermen's reports of freshwater and saltwater migrations of Nova Scotia eels (Anguilla rostrata). Can Field Nat 83:132-138

Moriarty C (1983) Age determination and growth rate of eels Anguilla anguilla (L). J Fish Biol 23:257-264

Moriarty C, Dekker W (eds) (1997) Management of the European eel. Mar Inst Fish Bull No 15, Dublin

Morrison WE, Secor DH, Piccoli PM (2003) Estuarine habitat use by Hudson River American eels as determined by otolith strontium:calcium ratios. In: Dixon DA (ed) Biology, management, and protection of catadromous eels. Am Fish Soc Symp 33:87-100

Mosegaard H, Svedang H, Taberman K (1988) Uncoupling of somatic and otolith growth rates in Arctic charr (Salvelinus alpinus) as an effect of differences in temperature response. Can J Fish Aquat Sci 45:1514-1524

Oliveira K (1996) Field validation of annular growth rings in the American eel, Anguilla rostrata, using tetracyclinemarked otoliths. US Fish Bull 94:186-189

Oliveira K (1999) Life history characteristics and strategies of the American eel, Anguilla rostrata. Can J Fish Aquat Sci 56:795-802

Oliveira K, McCleave JD (2000) Variation in population and life history traits of the American eel, Anguilla rostrata, in four rivers in Maine. Environ Biol Fishes 59:141-151

Oliveira K, McCleave JD (2002) Sexually different growth histories of the American eel in four rivers in Maine. Trans Am Fish Soc 131:203-211

Otake T, Ishii T, Nakahara M, Nakamura R (1994) Drastic changes in otolith strontium/calcium ratios in leptocephali and glass eels of Japanese eel Anguilla japonica. Mar Ecol Prog Ser 112:189-193

Panfili J, Ximenes MC (1992) Measurements on ground or sectioned otoliths: possibilities of bias. J Fish Biol 41: 201-207

Panfili J, Ximénès MC, Crivelli AJ (1994) Sources of variation in growth of the European eel (Anguilla anguilla) estimated from otoliths. Can J Fish Aquat Sci 51:506-515

Peterson RH (ed) (1997) The American eel in eastern Canada: stock status and management strategies. Proc Eel Workshop, January 13-14, 1997, Québec City. Can Tech Rep Fish Aquat Sci No 2196

Peterson, RH, Martin-Robichaud DJ (1994) First feeding and growth of elvers of the American eel (Anguilla rostrata Lesueur) at several temperature regimes. Can Tech Rep Fish Aquat Sci No 2013

Pierce CL, Rasmussen JB, Leggett WC (1996) Back-calculation of fish length from scales: empirical comparison of proportional methods. Trans Am Fish Soc 125:889-898

Poole WR, Reynolds JD (1996a) Age and growth of yellow eel, Anguilla anguilla (L.), determined by two different methods. Ecol Freshw Fish 5:86-95

Poole WR, Reynolds JD (1996b) Growth rate and age at migration of Anguilla anguilla. J Fish Biol 48:633-642

Quinn TJ ll, Deriso RB (1999) Quantitative fish dynamics. Oxford University Press, New York

Ricker WE (1975) Computations and interpretation of biological statistics of fish populations. Fish Res Board Can Bull 191

Rijnsdorp AD (1993) Fisheries as a large-scale experiment 
on life-history evolution: disentangling phenotypic and genetic effects in changes in maturation and reproduction of North Sea plaice, Pleuronectes platessa L. Oecologia 96:391-401

SAS (2001) Proc mixed, Release 8.2. SAS Institute, Cary, NC

Schirripa MJ (2002) An evaluation of back-calculation methodology using simulated otolith data. US Fish Bull 100: 789-799

Secor DH (1999) Specifying divergent migrations in the concept of stock: the contingent hypothesis. Fish Res 43: $13-34$

Secor DH, Dean JM (1989) Somatic growth effects on the otolith-fish size relationship in young pond-reared striped bass, Morone saxatilis. Can J Fish Aquat Sci 46: 113-121

Secor DH, Rooker JR (2000) Is otolith strontium a useful scalar of life cycles in estuarine fishes? Fish Res 46:359-371

Secor DH, Henderson-Arzapalo A, Piccoli PM (1995) Can otolith microchemistry chart patterns of migration and habitat utilization in anadromous fishes. J Exp Mar Biol Ecol 192:15-33

Shiao JC, Iizuka Y, Chang CW, Tzeng WN (2003) Disparities in habitat use and migratory behavior between tropical eel Anguilla marmorata and temperate eel A. japonica in four Taiwanese rivers. Mar Ecol Prog Ser 261:233-242

Smith WM, Saunders JW (1955) The American eels in certain fresh waters of the Maritime Provinces of Canada. J Fish Res Board Can 12:238-269

S-Plus (2001) S-Plus 6 for Windows. Insightful, Seattle

Stokes K, Law R (2000) Fishing as an evolutionary force. Mar Ecol Prog Ser 208:307-309

Svedäng H (1999) Vital population statistics of the exploited eel stock on the Swedish west coast. Fish Res 40:251-165

Svedäng H, Neuman E, Wickström H (1996) Maturation patterns in female European eel: age and size at the silver eel stage. J Fish Biol 48:342-351

Tatsukawa K (2003) Eel resources in East Asia. In: Aida K, Tsukamoto K, Yamauchi K (eds) Eel biology. SpringerVerlag, Tokyo, p 293-300

Tesch FW (1977) The eel: biology and management of Anguillid eels. Chapman \& Hall, London

Trippel EA (1995) Age at maturity as a stress indicator in fisheries. Bioscience 45:759-771

Tsukamoto K, Arai T (2001) Facultative catadromy of the eel Anguilla japonica between freshwater and seawater habitats. Mar Ecol Prog Ser 220:265-276

Tsukamoto K, Aoyama J, Miller MJ (2002) Migration, speciation, and the evolution of diadromy in anguillid eels. Can J Fish Aquat Sci 59:1989-1998

Editorial responsibility: Kenneth Sherman (Contributing Editor), Narragansett, Rhode Island, USA
Tzeng WN (1996) Effects of salinity and ontogenetic movements on strontium:calcium ratios in the otoliths of Japanese eel, Anguilla japonica Temminck and Schlegel. J Exp Mar Biol Ecol 199:11-122

Tzeng WN, Tsai YC (1994) Changes in otolith microchemistry of the Japanese eel, Anguilla japonica, during its migration from the ocean to the rivers of Taiwan. J Fish Biol 45: 671-683

Tzeng WN, Wu HF, Wickström H (1994) Scanning electron microscope analysis of annulus microstructure in otolith of European eel, Anguilla anguilla. J Fish Biol 45:479-492

Tzeng WN, Severin KP, Wickström H (1997) Use of otolith microchemistry to investigate the environmental history of European eel Anguilla anguilla. Mar Ecol Prog Ser 149: $73-81$

Tzeng WN, Lin HR, Wang CH, Xu SN (2000a) Differences in size and growth rates of male and female migrating Japanese eels in Pearl River, China. J Fish Biol 57: $1245-1253$

Tzeng WN, Wang CH, Wickström H, Reizenstein M (2000b) Occurrence of the semi-catadromous European eel Anguilla anguilla in the Baltic Sea. Mar Biol 137:93-98

Tzeng WN, Shiao JC, Iizuka Y (2002) Use of otolith Sr:Ca ratios to study the riverine migratory behaviors of Japanese eel Anguilla japonica. Mar Ecol Prog Ser 245:213-221

Tzeng WN, Iizuka Y, Shiao JC, Yamada Y, Oka HP (2003) Identification and growth rates comparison of divergent migratory contingents of Japanese eel (Anguilla japonica). Aquaculture 216:77-86

US Naval Oceanographic Office (1967) Oceanographic atlas of the North Atlantic Ocean, Section II, Physical properties. Publication No 700. US Naval Oceanographic Office, Washington, DC

Vøllestad LA (1992) Geographic variation in age and length at metamorphosis of maturing European eel: environmental effects and phenotypic plasticity. J Anim Ecol 61:41-48

Wang YG, Milton DA (2000) On comparison of growth curves: How do we test whether growth rates differ? US Fish Bull 98:874-880

Watt WD (1986) The case for liming some Nova Scotia salmon waters. Water Air Soil Pollut 31:775-789

Watt WD, Scott CD, Mandell P (1995) Water chemistry data from a monitoring program designed to detect changes in the long range transport of acidic pollutants into Nova Scotia's acidified Atlantic salmon rivers. Can Data Rep Fish Aquat Sci 972

Wright PJ (1991) The influence of metabolic rate on otolith increment width in Atlantic salmon parr, Salmo salar L. J Fish Biol 38:929-933

Submitted: July 25, 2003; Accepted: January 15, 2004

Proofs received from author(s): April 22, 2004 